\title{
Analysis on Sportspersonship Orientations of Students Studying in Faculty of Sports Sciences/School of Physical Education and Sports
}

\section{Özgür Karataş ${ }^{\circledR}$ Buğra Çağatay Savaş ${ }^{2}$}

İnönü Üniversity, Sports Science Faculty, Malatya, Turkey Email:bahaecelikel23@gmail.com

¿Inönü Üniversity Ph.D. in Health Sciences Institute Malatya, Turkey

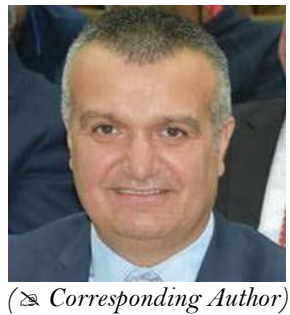

Abstract

The purpose of this study is to analyze the sportspersonship orientations of students studying in the faculty of sports sciences/school of physical education and sports by different variables. The population of this descriptive research is composed of the students studying in faculty of sports sciences/school of physical education and sports in six different universities while the sample is composed of 949 students studying in different grades and departments. As the data collection tool, personal information questionnaire and "Multidimensional Sportspersonship Orientation Scale-MSOS" developed by Vallerand et al. (1997) of which reliability and validity of Turkish version was ensured by Sezen-Balçıkanlı (2010) were used. The scale comprises of four subdimensions and 20 questions. The reliability coefficient of the multidimensional sportspersonship orientation scale was found to be (0.89). Data were analyzed in statistical package program. In the analysis of the study, arithmetic mean, standard deviation, independent samples $t$ test and one way variance analysis were used. It has been determined in the study that the multidimensional sportspersonship orientation of students is high. It has also been ascertained that there are significant difference in the variables of sex, age and the grade studied in terms of the multidimensional sportspersonship orientation of students $(\mathrm{p}<0.05)$. However, no significant difference was observed in the variables of the university studied and doing sports $(\mathrm{p}>0.05)$. It has been concluded that the variables of university studied and doing sports aren't effective on sportspersonship orientation of students while the variables of sex, age and the grade studied are effective on sportspersonship orientation of students.

Keywords: Sportspersonship, Faculty of sports sciences, School of physical education and sports

Citation | Özgür Karataş; Buğra Çağatay Savaş (2019). Analysis on Sportspersonship Orientations of Students Studying in Faculty of Sports Sciences/School of Physical Education and Sports. Asian Journal of Education and Training, 5(1): 151-158.

History:

Reived: 14 November 2018

Revised: 10 December 2018

Accepted: 18 January 2019

Published: 21 February 2019

Licensed: This work is licensed under a Creative Commons

Attribution 3.0 License (cc)

Publisher: Asian Online Journal Publishing Group
Contribution/Acknowledgement: Both authors contributed to the conception and design of the study.

Funding: This study received no specific financial support.

Competing Interests: The authors declare that they have no conflict of interests.

Transparency: The authors confirm that the manuscript is an honest, Transparency: The authors confirm that the manuscript is an honest,
accurate, and transparent account of the study was reported; that no vital accurate, and transparent account of the study was reported; that no vital
features of the study have been omitted; and that any discrepancies from the study as planned have been explained.

Ethical: This study follows all ethical practices during writing.

\section{Contents}

1. Introduction

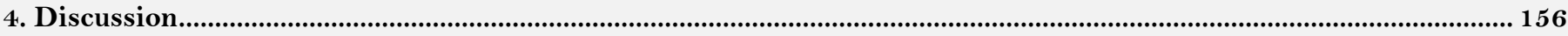

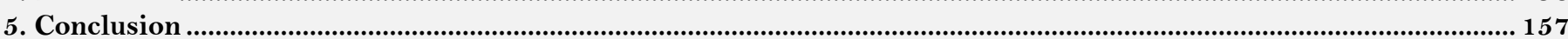

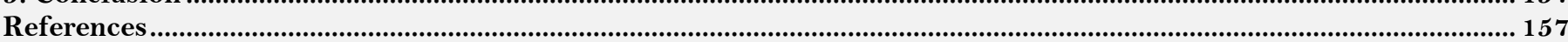




\section{Introduction}

Sportsman is defined as "person having the values required by sports" and sportspersonship is defined as "state of being sportsman (TDK). In sports competitions, all interested parties together with the audience await a completion performed with the spirit of true sportspersonship. Sportspersonship behavior expresses fair play and respect towards teammates, rivals, sports officials and other sports participants before, during and after the competition (Christian-Elendu and Dennis, 2017). The researches show that the sense of winning in sports is becoming more important today and causes moral problems that promote antisocial behavior (Stornes and Bru, $2002)$.

According to Feezell (1986) sportspersonship requires virtuous and normative behaviors which exist in the spirit of sports. A defeat of an athlete over her/his rival with a superior game and by avoiding unfair advantage incorporate behaving the rival kindly. Arnold (1984) argues that treating opponents with respect, compassion, sacrifice and generosity is one of the most important characteristics of the sportspersonship behavior. Virtue in sports terms, complying with the rules and the principle of equality, not using unethical ways, remaining calm in every case, "doing sports for sports" are the other characteristics sought in athletes (Erdemli, 1996).

Morals is defined as "a set of principles and values that allow distinguishing between right and wrong" (Pay, 2012) and "the self-control of the person without coercion, pulling oneself together with the effect of superego, mind, will, conscience and the emotions". Morals is also defined as "an internal strength that leads the person towards the goodness" (Aydin, 2011).

According to Orhun (1992) one of the main purposes of the education provided at schools is bring youth in such concepts as morals, rules and sportspersonship. It is attempted to convey these concepts to the students through sports activities and physical education grades. In this regard, it is stated that the students taking physical education and sports grade should develop their communication skills, and the characteristics of cooperation, fair play, social responsibility, leadership, sensitivity to nature and respect for differences" and they should get the habit of behaving in line with the sense of fair play (MEB, 2018). In order to contribute to the development of moral values of athletes, it will be beneficial to training them regarding sports ethics and sports morals. As the sports morals develops, the sense of sportspersonship and fair play will also develop. Everyone should be aware of the fact that sports morals of young people will only be established through education not automatically (Gürpinar, 2014).

As Erdemli (2012) states, the fair play problem occurs if sports is done professionally and amateurism is eliminated. The solution of this problem is only possible with education. Unlike amateur performance of sports, it is necessary to train athletes for virtuous behavior in professional sports. Otherwise, the athlete who accepts every behavior in a natural manner will exhibit extremely "rude and primitive" behaviors when the ambition to win prevails. In this case, there will be no values such as enthusiasm, tolerance, fraternity, accepting your opponent as friends and love and "the athlete will be lost."

According to Yildiran (2004) fair play concept known to have been used in sports as of the 18th century and created in England in the 19th century (Renson, 2009) is defined as "patient, consistent and conscious compliance of athletes with the rules during the matches even under the difficult conditions, not accepting unfair advantages in order not to break the equality of opportunities, not trying to get benefit from the unfair disadvantages of the rival, valuing and considering the rival as an individual and partner with equal rights who ensures the realization of match rather than seeing as an enemy”.

As believed by Pehlivan (2004) fair play means accepting and applying the fair and honest competition as a moral situation as a matter of importance attached to the human dignity.

Veronica (2010) has stated that fair play is a concept that contains obeying the written and unwritten rules of sports and respecting the opponent accordingly and emphasizes the moral dimension of the sports behaviors. It is analyzed with the meaning of "unbiased game" all over the world as a special term, different evaluations are made and its dissemination in sports is aimed.

Fair play is defined as "a honest game, a game played based on rules and mutual tolerance” (TDK).

Table-1. Perception of Sports Lumpkin et al.(2003); Sezen-Balçıkanlı (2017)

\begin{tabular}{|c|c|c|}
\hline \multirow{3}{*}{ Motivation } & Ideal & Reality \\
\hline & Good & Bad \\
\hline & Excellent Play & Winning At All Costs \\
\hline Purpose & $\begin{array}{l}\text { - Sportspersonship } \\
\text { - Good Play Strategies }\end{array}$ & $\begin{array}{l}\text { - Deceit } \\
\text { - Tricky Play Strategies }\end{array}$ \\
\hline \multirow[b]{2}{*}{ Behavior } & Correct & Incorrect \\
\hline & $\begin{array}{l}\text { Purpose: Gaining and Advantage } \\
\text { through Excellence }\end{array}$ & $\begin{array}{l}\text { Purpose: Sending the Opponent Off the Play, Giving Physical, } \\
\text { Emotional and Mental Damage }\end{array}$ \\
\hline
\end{tabular}

Source: Obtained from primary data

In Table 1, the relation between the ideal and real has been analyzed in the dimensions of motivation, purpose and behavior. What is ideal should be winning with an excellent game and sportspersonship. Winning by sending the opponent off at all costs by thinking of various tricks expresses the behavior that takes place against the spirit of fair play. The thought of absolute winning in sports may result in the accepting and rewarding the violence against the opponent and moral deterioration (Lumpkin et al., 2003; Sezen-Balçıkanlı, 2017); (Sezen-Balçıkanlı, $2017)$.

Contest in sports foresees competing/contesting with the opponent based on the pre-determined rules of game/competition. The competition should be realized by making more effort than the opponent within the framework of respect (Boxill, 2003; Sezen-Balçıkanlı, 2017). In this case, fair play has two dimensions. The behaviors that are adhered to the written rules of the competition/game are called "formal-written fair play". The behaviors being out of the written rules, aiming to compete with the opponent in equal conditions, not foreseeing the unfair winning, having the false referee decisions corrected despite being in favor of oneself, not thinking about to give physical and mental damage to the opponent and based on not to exhibit extreme behaviors when losing are 
called "informal-unwritten fair play" (Yıldıran, 2004). According to Pehlivan (2004) fair play principle states that you can support your team but you don't have the right to insult the other team.

Donuk and Senduran (2006) states that fair play is "good game", "a good mood that suits the athlete" and "positive attitudes and behaviors". Actually, this should be thought as a lifestyle in sports. According to Sahin (2016) protecting and developing the spirit of sportspersonship and all participants' exhibiting behaviors in line with this understanding will contribute to the prevention of violence and aggression. Due to the fact that the attitudes and behaviors directed to fair play can reveal themselves differently in various ways of doing sports such as sports branches, sex, age, contact, doing individual-team sports, being professional-amateur, they should be considered as variables in studies analyzing the sports-morals relation (Sezen-Balçıkanlı, 2017).

\section{Material and Method}

Research population is composed of the students studying in Faculty of Sports Sciences and School of Physical Education and School of Physical Education and Sports (BESYO) in six different universities (İnönü, Atatürk, Gaziantep, Fırat, Yüzüncü yıl and Muş Alpaslan) for 2017-2018 academic year and the sample is composed of randomly selected students $(\mathrm{n}=949)$ studying in these faculties/schools.

As the data collection tool, personal information questionnaire and "Multidimensional Sportspersonship Orientation Scale-MSOS" developed by Vallerand et al. (1997) of which reliability and validity of Turkish version was ensured by Sezen-Balçıkanlı (2010) were used. The scale comprises of four sub-dimensions and 20 questions.

Concerning the distribution of answers given to the scale questions, it has been determined that the reliability coefficient Cronbach's Alpha is (0.82) for compliance with social norms, respect for rules and management is (0.74), commitment to responsibilities in sports $(0.76)$ and respect for the opponent is (0.78). The total reliability coefficient of the scale was found to be (0.89). Data were analyzed in SPSS 24 statistical package program. Frequency, percentage and arithmetic mean, independent samples t test and ANOVA tests were used to find the distribution of participants. The results obtained from the distributions are shown in tables, the findings have been interpreted and necessary solution offers have been presented.

\section{Findings}

Table-2. Characteristics of students related to the demographic variables

\begin{tabular}{|c|c|c|c|}
\hline Variable & Group & $f$ & $\%$ \\
\hline \multirow{7}{*}{ University studied } & İnönü & 247 & 26.0 \\
\hline & Atatürk & 182 & 19.2 \\
\hline & Gaziantep & 151 & 15.9 \\
\hline & Firat & 162 & 17.1 \\
\hline & Yüzüncüyıl & 177 & 18.7 \\
\hline & MuşAlpaslan & 30 & 3.2 \\
\hline & Total & 949 & 100 \\
\hline \multirow{3}{*}{ Sex } & Male & 615 & 64.8 \\
\hline & Female & 334 & 35.2 \\
\hline & Total & 949 & 100.0 \\
\hline \multirow{5}{*}{ Age } & $18-20$ & 373 & 39.3 \\
\hline & $21-23$ & 270 & 28.5 \\
\hline & $24-26$ & 217 & 22.9 \\
\hline & 27 and above & 89 & 9.4 \\
\hline & Total & 949 & 100.0 \\
\hline Variable & Group & f & $\%$ \\
\hline \multirow{5}{*}{ Grade } & $2^{\text {nd }}$ Grade & 212 & 22.3 \\
\hline & $3^{\text {rd }}$ Grade & 280 & 29.5 \\
\hline & $4^{\text {th }}$ Grade & 193 & 20.3 \\
\hline & Total & 949 & 100.0 \\
\hline & $2^{\text {nd }}$ Grade & 212 & 22.3 \\
\hline \multirow{3}{*}{ Doing Sports } & Yes & 902 & 95.0 \\
\hline & No & 47 & 5.0 \\
\hline & Total & 949 & 100.0 \\
\hline
\end{tabular}

Source: Obtanied from primary data

Table 2 shows the information about the demographic distribution of the students participating in the research. It has been established that the highest participation is 247 students (26.0\%) from İnönü University, 615 of them $(64.8 \%)$ are male and 334 of them $(35.2 \%)$ are female. 373 students $(39.3 \%)$ are in the age group of $18-20,270$ students $(28.5 \%)$ are in the age group of $21-23.264$ students $(27.8 \%)$ are in the $1^{\text {st }}$ grade, 193 students $(20.3 \%)$ study in the $4^{\text {th }}$ grade. 902 of the students $(95.0 \%)$ have stated to do sports. 
Table-3. MSOS ANOVA results of students by the variable of the university studied

\begin{tabular}{|c|c|c|c|c|c|c|c|}
\hline Sub-dimensions & Variable & $\mathbf{N}$ & $\bar{X}$ & SS & Sd & $\mathbf{F}$ & $\mathbf{p}$ \\
\hline \multirow{7}{*}{ Compliance with the Social Norms } & İnönü U. & 247 & 3.549 & .682 & \multirow{3}{*}{5} & \multirow{7}{*}{.858} & \multirow{7}{*}{.509} \\
\hline & Atatürk U. & 182 & 3.531 & .677 & & & \\
\hline & Gaziantep U. & 151 & 3.551 & .627 & & & \\
\hline & Firat U. & 162 & 3.538 & .590 & \multirow{3}{*}{943} & & \\
\hline & Yüzüncüyıl U. & 177 & 3.456 & .731 & & & \\
\hline & Muş Alpaslan U. & 30 & 3.360 & .737 & & & \\
\hline & Total & 949 & 3.521 & .669 & 948 & & \\
\hline \multirow{7}{*}{ Respect for Rules and Management } & İnönü U. & 247 & 3.616 & .616 & \multirow{3}{*}{5} & \multirow{7}{*}{1.422} & \multirow{7}{*}{.214} \\
\hline & Atatürk U. & 182 & 3.627 & .681 & & & \\
\hline & Gaziantep U. & 151 & 3.662 & .600 & & & \\
\hline & Firat U. & 162 & 3.596 & .563 & \multirow{3}{*}{943} & & \\
\hline & Yüzüncüyıl U. & 177 & 3.491 & .697 & & & \\
\hline & Muş Alpaslan U. & 30 & 3.586 & .666 & & & \\
\hline & Total & 949 & 3.598 & .636 & 948 & & \\
\hline \multirow{7}{*}{ Commitment to Responsibilities in Sports } & İnönü U. & 247 & 3.854 & .746 & \multirow{3}{*}{5} & \multirow{7}{*}{1.019} & \multirow{7}{*}{.405} \\
\hline & Atatürk U. & 182 & 3.838 & .746 & & & \\
\hline & Gaziantep U. & 151 & 3.786 & .698 & & & \\
\hline & Firat U. & 162 & 3.800 & .670 & \multirow{3}{*}{943} & & \\
\hline & Yüzüncüyıl U. & 177 & 3.709 & .743 & & & \\
\hline & Muş Alpaslan U. & 30 & 3.713 & .789 & & & \\
\hline & Total & 949 & 3.799 & .727 & 948 & & \\
\hline \multirow{7}{*}{ Respect for the Opponent } & İnönü U. & 247 & 3.280 & .793 & \multirow{3}{*}{5} & \multirow{7}{*}{.277} & \multirow{7}{*}{.926} \\
\hline & Atatürk U. & 182 & 3.260 & .825 & & & \\
\hline & Gaziantep U. & 151 & 3.229 & .797 & & & \\
\hline & Firat U. & 162 & 3.290 & .766 & \multirow{3}{*}{943} & & \\
\hline & Yüzüncüyıl U. & 177 & 3.218 & .832 & & & \\
\hline & Muş Alpaslan U. & 30 & 3.173 & .934 & & & \\
\hline & Total & 949 & 3.255 & .806 & 948 & & \\
\hline \multirow{7}{*}{ MSOS Mean } & İnönü U. & 247 & 3.575 & .577 & \multirow{3}{*}{5} & \multirow{7}{*}{.978} & \multirow{7}{*}{.430} \\
\hline & Atatürk U. & 182 & 3.564 & .601 & & & \\
\hline & Gaziantep U. & 151 & 3.557 & .544 & & & \\
\hline & Firat U. & 162 & 3.556 & .487 & \multirow{3}{*}{943} & & \\
\hline & Yüzüncüyıl U. & 177 & 3.468 & .601 & & & \\
\hline & Muş Alpaslan U. & 30 & 3.458 & .633 & & & \\
\hline & Total & 949 & 3.543 & .569 & 948 & & \\
\hline
\end{tabular}

The findings obtained by the variable of university of students are shown in Table 3. In this regard, no significant difference was observed in the MSOS scale mean scores and sub-dimensions $(p>0.05)$. In terms of MSOS scale, the highest mean score $(\overline{\mathrm{X}}=3.575)$ belongs to students in İnönü University and the lowest mean score $(\overline{\mathrm{X}}=3.458)$ belongs to the students in Muş Alpaslan University. It can be stated that the multidimensional sportpersonship orientation of the participant students studying in different universities $(\overline{\mathrm{X}}=3,543)$ are high (high=3.43-4.23).

Table-4. Comparison of MSOS scores of students by the variable of sex (t-test)

\begin{tabular}{|c|c|c|c|c|c|c|}
\hline Sub-dimensions & Sex & $\mathbf{N}$ & $\bar{X}$ & SS & $\mathbf{t}$ & $\mathbf{p}$ \\
\hline \multirow{2}{*}{ Compliance with Social Norms } & Male & 615 & 3.509 & .683 & \multirow{2}{*}{-.723} & \multirow{2}{*}{.470} \\
\hline & Female & 334 & 3.542 & .643 & & \\
\hline \multirow{2}{*}{ Respect for Rules and Management } & Male & 615 & 3.525 & .612 & \multirow{2}{*}{-4.822} & \multirow{2}{*}{.000} \\
\hline & Female & 334 & 3.731 & .658 & & \\
\hline \multirow{2}{*}{ Commitment to Responsibilities in Sports } & Male & 615 & 3.762 & .744 & \multirow{2}{*}{-2.141} & \multirow{2}{*}{.033} \\
\hline & Female & 334 & 3.868 & .690 & & \\
\hline \multirow{2}{*}{ Respect for the Opponent } & Male & 615 & 2.990 & .739 & \multirow{2}{*}{-15.302} & \multirow{2}{*}{.000} \\
\hline & Female & 334 & 3.741 & .690 & & \\
\hline \multirow{2}{*}{ Mean MSOS } & Male & 615 & 3.447 & .557 & \multirow{2}{*}{-7.277} & \multirow{2}{*}{.000} \\
\hline & Female & 334 & 3.721 & .548 & & \\
\hline
\end{tabular}

Analyzing the MSOS Scale and sub-dimension mean scores of students by the variable of sex, it is observed that there is a significant difference between females and males in scale mean scores and all sub-dimensions except for the first sub-dimension (compliance with social norms) by the variable sex $(p<0.05)$. It can be stated that females have higher MSOS than males. 
Table-5. MSOS ANOVA results of students by the variable of age

\begin{tabular}{|c|c|c|c|c|c|c|c|c|c|}
\hline \multirow{2}{*}{ Sub-dimensions } & \multirow{2}{*}{ Variable } & \multirow{2}{*}{$\mathbf{N}$} & \multirow{2}{*}{$\bar{X}$} & \multirow{2}{*}{ SS } & \multirow{2}{*}{ Sd } & \multirow{2}{*}{$\mathbf{F}$} & \multirow{2}{*}{$\mathbf{p}$} & \multicolumn{2}{|c|}{ Post Hoc Test } \\
\hline & & & & & & & & Groups & p \\
\hline \multirow{5}{*}{$\begin{array}{l}\text { Compliance with Social } \\
\text { Norms }\end{array}$} & $18-20(1)$ & 373 & 3.498 & .658 & \multirow{2}{*}{3} & \multirow{5}{*}{10.973} & \multirow{5}{*}{.000} & \multicolumn{2}{|l|}{ Tamhane } \\
\hline & $21-23(2)$ & 270 & 3.563 & .716 & & & & \multirow{4}{*}{\begin{tabular}{|l}
$(3)>(4)$ \\
$(3)>(1)$ \\
$(1)>(4)$ \\
$(2)>(4)$
\end{tabular}} & \multirow{4}{*}{$\begin{array}{l}.000 \\
.034 \\
.000 \\
.000\end{array}$} \\
\hline & 24-26(3) & 217 & 3.646 & .599 & \multirow{2}{*}{945} & & & & \\
\hline & $27+(4)$ & 89 & 3.182 & .616 & & & & & \\
\hline & Total & 949 & 3.521 & .669 & 948 & & & & \\
\hline \multirow{5}{*}{$\begin{array}{l}\text { Respect for Rules and } \\
\text { Management }\end{array}$} & $18-20(1)$ & 373 & 3.711 & .639 & \multirow{2}{*}{3} & \multirow{5}{*}{8.763} & \multirow{5}{*}{.000} & \multirow{5}{*}{$\begin{array}{l}\text { Tukey } \\
(1)>(2)\end{array}$} & \multirow{5}{*}{.000} \\
\hline & $21-23(2)$ & 270 & 3.454 & .613 & & & & & \\
\hline & $24-26(3)$ & 217 & 3.577 & .625 & \multirow{2}{*}{945} & & & & \\
\hline & $27+(4)$ & 89 & 3.609 & .636 & & & & & \\
\hline & Total & 949 & 3.598 & .636 & 948 & & & & \\
\hline \multirow{5}{*}{$\begin{array}{l}\text { Commitment } \\
\text { Responsibilities } \\
\text { Sports }\end{array}$} & $18-20(1)$ & 373 & 3.788 & .652 & \multirow{2}{*}{3} & \multirow{5}{*}{9.096} & \multirow{5}{*}{.000} & \multirow{5}{*}{$\begin{array}{l}\text { Tamhane } \\
(1)<(2) \\
(3)<(2) \\
(1)>(4) \\
(2)>(4)\end{array}$} & \multirow{5}{*}{$\begin{array}{l}.028 \\
.028 \\
.033 \\
.000\end{array}$} \\
\hline & $21-23(2)$ & 270 & 3.946 & .726 & & & & & \\
\hline & 24-26(3) & 217 & 3.757 & .733 & \multirow{2}{*}{945} & & & & \\
\hline & $27+(4)$ & 89 & 3.503 & .898 & & & & & \\
\hline & Total & 949 & 3.799 & .727 & 948 & & & & \\
\hline & $18-20(1)$ & 373 & 3.390 & .777 & 0 & & & & \\
\hline & $21-23(2)$ & 270 & 3.351 & .821 & 3 & & & $(2)>(4)$ & .003 \\
\hline Kespect for & $24-26(3)$ & 217 & 3.023 & .697 & & 15.358 & .000 & $(1)>(3)$ & .000 \\
\hline & $27+(4)$ & 89 & 2.961 & .928 & 945 & & & $(1)>(4)$ & .001 \\
\hline & Total & 949 & 3.255 & .806 & 948 & & & $(2)>(3)$ & .000 \\
\hline & $18-20(1)$ & 373 & 3.597 & .550 & & & & & \\
\hline & $21-23(2)$ & 270 & 3.579 & .551 & 3 & & & & \\
\hline Mean MSOS & $24-26(3)$ & 217 & 3.501 & .549 & & 6.806 & .000 & $\begin{array}{l}(4)<(2) \\
(1)>(4)\end{array}$ & $\begin{array}{l}.007 \\
009\end{array}$ \\
\hline & $27+(4)$ & 89 & 3.314 & .678 & 945 & & & & .002 \\
\hline & Total & 949 & 3.543 & .569 & 948 & & & & \\
\hline
\end{tabular}

Table 5 reveals the findings obtained regarding the variable of age. Looking at the findings, a significant difference is observed between the age groups in MSOS sub-dimensions and scale mean scores $(\mathrm{p}<0.05)$. The lowest mean score belongs to the age group of 27 and above for the sub-dimensions of the compliance with social norms, commitment to responsibilities in sports and respect for the opponent while the lowest mean score is observed in the age group of 21-23 for the sub-dimension of respect for rules and management. The lowest mean score in terms of MSOS scale mean score belongs to the age group of 27 and above while the highest mean score is observed in the age group of 18-20. It is observed that the higher the age group is, the lower mean scores are.

Table-6. MSOS ANOVA results of students by the variable of grade studied

\begin{tabular}{|c|c|c|c|c|c|c|c|c|c|}
\hline \multirow{2}{*}{ Sub-dimensions } & \multirow{2}{*}{ Variable } & \multirow{2}{*}{$\mathbf{N}$} & \multirow{2}{*}{$\bar{X}$} & \multirow{2}{*}{ SS } & \multirow{2}{*}{ Sd } & \multirow{2}{*}{$\mathbf{F}$} & \multirow[b]{2}{*}{$\mathbf{p}$} & \multicolumn{2}{|c|}{ Post Hoc Test } \\
\hline & & & & & & & & Groups & $\mathbf{p}$ \\
\hline \multirow{5}{*}{ Compliance with Social Norms } & $1^{\text {st }}$ Grade (1) & 316 & 3.519 & .641 & \multirow{2}{*}{3} & \multirow{5}{*}{4.862} & \multirow{5}{*}{.002} & \multicolumn{2}{|l|}{ Tukey } \\
\hline & $2^{\text {nd }}$ Grade (2) & 197 & 3.655 & .730 & & & & \multirow{4}{*}{$(2)>(4)$} & \multirow{4}{*}{.001} \\
\hline & $3^{\text {rd }}$ Grade (3) & 276 & 3.504 & .632 & \multirow{2}{*}{945} & & & & \\
\hline & $4^{\text {th }}$ Grade $(4)$ & 160 & 3.388 & .684 & & & & & \\
\hline & Total & 949 & 3.521 & .669 & 948 & & & & \\
\hline \multirow{5}{*}{$\begin{array}{l}\text { Respect for } \\
\text { Management }\end{array}$} & $1^{\text {st }}$ Grade (1) & 316 & 3.767 & .578 & \multirow{2}{*}{3} & \multirow{5}{*}{12.350} & \multirow{5}{*}{.000} & \multirow{5}{*}{$\begin{array}{l}\text { Tamhane } \\
(1)>(2) \\
(1)>(3) \\
(1)>(4)\end{array}$} & \multirow{5}{*}{$\begin{array}{l}.000 \\
.000 \\
.025\end{array}$} \\
\hline & $2^{\text {nd }}$ Grade (2) & 197 & 3.508 & .644 & & & & & \\
\hline & $3^{\text {rd }}$ Grade (3) & 276 & 3.481 & .587 & \multirow{2}{*}{945} & & & & \\
\hline & $4^{\text {th }}$ Grade $(4)$ & 160 & 3.573 & .742 & & & & & \\
\hline & Total & 949 & 3.598 & .636 & 948 & & & & \\
\hline \multirow{5}{*}{$\begin{array}{l}\text { Commitment to Responsibilities } \\
\text { in Sports }\end{array}$} & $1^{\text {st }}$ Grade (1) & 316 & 3.810 & .632 & \multirow{2}{*}{3} & \multirow{5}{*}{2.396} & \multirow{5}{*}{.067} & & \\
\hline & $2^{\text {nd }}$ Grade $(2)$ & 197 & 3.732 & .732 & & & & & \\
\hline & $3^{\text {rd }}$ Grade $(3)$ & 276 & 3.881 & .766 & \multirow{2}{*}{945} & & & & \\
\hline & $4^{\text {th }}$ Grade $(4)$ & 160 & 3.721 & .812 & & & & & \\
\hline & Total & 949 & 3.799 & .727 & 948 & & & & \\
\hline \multirow{5}{*}{ Respect for the Opponent } & $1^{\text {st }}$ Grade (1) & 316 & 3.386 & .770 & \multirow{2}{*}{3} & & & Tukey & \\
\hline & $2^{\text {nd }}$ Grade (2) & 197 & 3.362 & .807 & & & & $(1)>(3)$ & .000 \\
\hline & $3^{\text {rd }}$ Grade (3) & 276 & 3.104 & .785 & & 8.842 & .000 & $(1)>(4)$ & .004 \\
\hline & $4^{\text {th }}$ Grade (4) & 160 & 3.122 & .850 & 945 & & & $(2)>(3)$ & .003 \\
\hline & Total & 949 & 3.255 & .806 & 948 & & & $(2)>(4)$ & .024 \\
\hline & $1^{\text {st }}$ Grade (1) & 316 & 3.620 & .535 & & & & & \\
\hline & $2^{\text {nd }}$ Grade $(2)$ & 197 & 3.564 & .592 & 3 & & & Tamhane & \\
\hline Mean MSOS & $3^{\text {rd }}$ Grade (3) & 276 & 3.493 & .522 & & 4.195 & .006 & $(1)>(3)$ & .021 \\
\hline & $4^{\text {th }}$ Grade (4) & 160 & 3.451 & .658 & 945 & & & $(1)>(4)$ & .031 \\
\hline & Total & 949 & 3.543 & .569 & 948 & & & & \\
\hline
\end{tabular}

Table 6 reveals the findings obtained regarding the variable of grade of students. It is observed concerning the findings that there is a significant difference between the grades in MSOS sub-dimensions and scale mean scores except for the dimension of the commitment to responsibilities in sports $(p<0.05)$. The lowest mean score is observed in the $4^{\text {th }}$ grade students in the sub-dimension of compliance with social norms and the highest mean score belongs to the students of $2^{\text {nd }}$ grade. The lowest mean score for the sub-dimension of respect for rules and management belongs to the $3^{\text {rd }}$ grade students and the highest mean score belongs to the students of the $1^{\text {st }}$ grade. 
In the sub-dimension of respect for the opponent, the lowest mean score belongs to the students of the $3^{\text {rd }}$ grade and the highest mean score belongs to the $1^{\text {st }}$ grade students. In the MSOS scale mean score, the lowest mean score is observed in the $4^{\text {th }}$ grade students and the highest mean score belongs to the students of the $1^{\text {st }}$ grade.

\begin{tabular}{|c|c|c|c|c|c|c|}
\hline Sub-dimensions & Doing Sports & $\mathbf{N}$ & $\overline{\boldsymbol{X}}$ & SS & $\mathbf{t}$ & $\mathbf{p}$ \\
\hline \multirow{2}{*}{ Compliance with Social Norms } & Yes & 902 & 3.504 & .660 & \multirow{2}{*}{-3.395} & \multirow{2}{*}{.001} \\
\hline & No & 47 & 3.842 & .752 & & \\
\hline \multirow{2}{*}{ Respect for Rules and Management } & Yes & 902 & 3.599 & .640 & \multirow{2}{*}{.261} & \multirow{2}{*}{.794} \\
\hline & No & 47 & 3.574 & .555 & & \\
\hline \multirow{2}{*}{ Commitment to Responsibilities in Sports } & Yes & 902 & 3.795 & .734 & \multirow{2}{*}{-.866} & \multirow{2}{*}{.387} \\
\hline & No & 47 & 3.889 & .574 & & \\
\hline \multirow{2}{*}{ Respect for the Opponent } & Yes & 902 & 3.248 & .809 & \multirow{2}{*}{-1.153} & \multirow{2}{*}{.249} \\
\hline & No & 47 & 3.387 & .731 & & \\
\hline \multirow{2}{*}{ Mean MSOS } & Yes & 902 & 3.536 & .570 & \multirow{2}{*}{-1.606} & \multirow{2}{*}{.109} \\
\hline & $\mathrm{No}$ & 47 & 3.673 & .524 & & \\
\hline
\end{tabular}

Table 7 shows the analysis results by the variable of doing sports. Analyzing the findings obtained, it is observed that there is a significant difference between those doing and not doing sports in the sub-dimension of compliance with the social norms $(\mathrm{p}<0.05)$. However, no significant difference was observed in terms of three subdimensions and scale mean score $(\mathrm{p}>0.05)$. In this regard, it can be stated that there isn't a difference between those doing and not doing sports in terms of MSOS.

Table-8. MSOS Scale levels of student.

\begin{tabular}{l|l|l|l}
\hline Scale Dimension & $\mathbf{N}$ & $\overline{\boldsymbol{X}}$ & SS \\
\hline Compliance with Social Norms & 949 & 3.521 & .669 \\
\hline Respect for Rules and Management & 949 & 3.598 & .636 \\
\hline Commitment to Responsibilities in Sports & 949 & 3.799 & .727 \\
\hline Respect for the Opponent & 949 & 3.255 & .806 \\
\hline Mean MSOS Scale & 949 & 3.543 & .569 \\
\hline$(\mathrm{p}<0.05)$ & \multicolumn{3}{|}{}
\end{tabular}

Table 8 indicates the MSOS scale mean scores of students. MSOS values of students are observed to be high $(\overline{\mathrm{X}}=3,543-$ - $3.43-4.23 ”)$.

\section{Discussion}

In Table 3, no significant difference could be determined in MSOS values of students by the variable of the university studied. In terms of MSOS scale, the highest mean score belongs to students in İnönü University and the lowest mean score belongs to the students in Muş Alpaslan University. It can be stated that the multidimensional sportpersonship orientation of the students $\left({ }^{-} \mathrm{X}=3.543\right)$ are high (high=3.43-4.23). In the study of Tel et al. (2017) conducted on the students of Faculty of Sports Sciences and in the study of Hacicaferoğlu et al. (2015) performed on secondary school students, they have stated that sportspersonship behaviors of students are lower than the expected level (moderate level).

It has been concluded in Table 4 that females have higher MSOS values than males. In the study of Tel et al. (2017) titled "Opinions of the Students in Faculty of Sports Sciences about the Sportspersonship Behaviors", it has been determined that females have higher sportspersonship scores than males. There are a lot of studies indicating that sportspersonship scores of females are higher (Tsai and Fung, 2005; Akandere et al., 2009; Gürpınar and Kurşun, 2013; Esentürk et al., 2015; Gümüş et al., 2016; Goksel and Zorba, 2017; Koç, 2017; Yilmaz et al., 2017). These findings are in parallel with the results of our study. Karafil et al. (2017) have stated that male secondary school students are more sporting than the females. In the study of Başaran et al. (2017) on BESYO students, the difference between the sportspersonship scores of females and males in the sub-dimension of respect for rules and management has been found significant in favor of females while there isn't any difference between other subdimensions. There are also other studies that didn't establish any significant difference in terms of the sportsperson ship orientations by the variable of sex (Gürpınar and Kurşun, 2013); (Kayışoğlu et al., 2015). It is thought that the reason women adopt more sportsmanship is because women have a more emotional structure. It is thought that the reason women adopt sportsperson ship more is that women have a more emotional structure (Gürpınar and Kurşun, 2013).

According to Table 5, the lowest MSOS score belongs to the age group of 27 and above while the highest mean score is observed in the age group of 18-20. It can be stated that the higher the age group is, the lower sportsperson ship orientation becomes. Previous studies (Tsai and Fung, 2005); (Esentürk et al., 2015) have found the sportsperson ship orientations of older athletes lower. This finding complies with our study. Gürpınar (2014) states that students start to exhibit un sportsperson ship orientations due to their increasing age and higher competition conditions. Goksel and Zorba (2017) express that sportsperson ship can get more importance while competing for small rewards at young ages; however, people can move away from the sportsperson ship due to increasing scale of reward in parallel to the age. Gürpınar and Kurşun (2013) have stated regarding MSOS that the sportsperson ship scores of athletes aged 22 and above are significantly higher than the athletes aged 21 and below in favor of 22-year old athletes concerning the sub-dimensions of respect for rules and management and respect for the opponent and total scores of scale. The fact that the desire to win takes the place of sportsperson ship at young ages due to their higher success desires and motivations can be thought to cause decreased sportsperson ship orientations in younger athletes. Similarly, Goksel and Zorba (2017) state that opposite results obtained by the 
variable of age can arise from the branch differences between participants, different sports environments, rules, fields and winning conditions.

In Table 6 , the lowest MSOS belongs to the $4^{\text {th }}$ grade students in terms of the grade studied and the highest MSOS belongs to the $1^{\text {st }}$ grade students. It is observed that sportsperson ship orientation reduces in parallel to the increase in grade level. There are also studies stating that sportsperson ship scores are higher in lower grades and lower in higher grades. In the study performed on secondary school students (Yilmaz et al., 2017 ) it has been determined that the higher the grade becomes, the lower the sportsperson ship behaviors of students are. Similar result is also observed in the studies of Yakup (2013) and Esentürk et al. (2015). Hacicaferoğlu et al. (2015) has concluded that there are significant differences among the students depending on the class level. Kayışoğlu et al. (2015) has stated that there isn't any statistically significant difference in terms of the class level.

In Table 7, a significant difference wasn't observed between those doing and not doing sports in terms of MSOS. Considering the values and ethical attitudes and behaviors provided by sports to the participants, this finding doesn't meet our expectations. However, it can be stated that the students being in the sampling but not doing sports reflect a temporary situation rather than a consistent one because it is irrational to think that the students of Faculty of Sports/BESYO stay out of sports, so the failure to find a significant difference has met our expectations. Akandere et al. (2009) have stated that the students doing sports in secondary education have higher ethical judgement level than those not doing sports. Başaran et al. (2017) have concluded that there are statistically significant differences between the sportsperson ship scores of the students actively doing sports and those not doing sports in the sub-dimensions of respect for rules and management and the commitment to the responsibilities in sports.

\section{Conclusion}

It has been concluded following the study that multidimensional sportsperson ship orientations of students are high. . It has also been ascertained that there are significant differences in the variables of sex, age and the grade studied in terms of the multidimensional sportsperson ship orientation of students $(p<0.05)$. However, no significant difference was observed in the variables of the university studied and doing sports ( $p>0.05)$. Analyzing the literature investigating the concept of sportsperson ship, it is possible to see that the relations between such universal principles as virtue, morality, tolerance, honesty, patience and friendship are evaluated and their importance are revealed. Dissemination of these principles in sports environment depends on whether the students of Faculty of Sports Sciences/BESYO have these principles. Thus, it is necessary that the students of sports departments at universities who will raise the future athletes and have the most important place in dissemination of sportsperson ship into the every field of sports should be trained in this field. In all schools, seminars, conferences and applied studies on sportsperson ship orientation can be organized to contribute to the personal development of students.

\section{References}

Akandere, M., G. Baştuğ and E.D. Güler, 2009. The effect of sports participation on the moral development of children in secondary schools. Niğde University Journal of Physical Education and Sports Sciences, 3(1): 59-68.

Arnold, J., 1984. Three approaches towards an understanding of sportspersonship. Journal of Philosophy of Sport, 3: 61-70.

Aydın, U., 2011. Ethics and ethics in public administration from theory to practice Kahramanmaraş Sütçü İmam University. Journal of Faculty of Economics and Administrative Sciences, 1(2): 39-50.

Başaran, Z., R.B. Erdoğan, Y. Körmükçü and H. Adalı, 2017. The examination of fair-play understanding of the students of the school of physical education and sports. Journal of Physical Education and Sports Studies, 9(1): 35-43.

Boxill, J., 2003. The ethics of competition. In Boxill J. (Editor). Sport Ethics an Anthology. USA: Blackwell. pp: 107-115.

Christian-Elendu, I. and M.I. Dennis, 2017. Over-emphasis on winning, host-to-win and winning at-all-cost syndrome in modern sports competitions: Implications for unsportsmanship behaviours of sports participant. International Journal of Physical Education, Sports and Health, 4(5): 104-107

Donuk, B. and F.S. Senduran, 2006. Anatomy of football. Istanbul: Ötüken Publications. pp: 57-65.

Erdemli, A., 1996. Human, sport and olympism. Istanbul: Sarmal Publishing.

Erdemli, A., 2012. Sports, humanism and olimpism. Istanbul University Philosophy Arkivi Journal, 30: 153-178.

Esentürk, O.K., E.L. Ilhan and O.B. Celik, 2015. Examination of high school students' sportsmanlike conducts in physical education less ons according to some variability. Science, Movement and Health, 15(2): 627-634.

Feezell, R.M., 1986. Sportsmanship. Journal of the Philosophy of Sport, 13(1): 1-13.

Goksel, A.G. and E. Zorba, 2017. The examination of sportsmanship behaviors of beach handball players in Turkey. Sport Journal, 20 : 1-9.

Gümüş, H., S. Saraçlı, Ö.F. Karakullukçu, G. Doğanay and S. Kurtipek, 2016. The concept of fair play in secondary school students. International Journal of Science Culture and Sport, 4(2): 430-438.

Gürpınar, B., 2014. Sports decision-making attitudes of athletes secondary and high school students in terms of sports variables. Education and Science, 39(176): 413-424.

Gürpınar, B. and S. Kurşun, 2013. Sports orientations of basketball players and footballers (Sportspersonship Orientations of Basketball and Soccer Players). Mediterranean Journal of Humanities, 3(1): 171-176.

Hacıcaferoğlu, S., M.H. Selçuk, B. Hacıcaferoğlu and Ö. Karataş, 2015. Investigation of the contribution of physical education and sport courses to sportistic behaviors in terms of some variables. International Journal of Science Culture and Sport, 3(4): 557-566. Available at: https://doi.org/10.14486/ijscs431.

Karafil, A.Y., A. Emrah, U. Mehmet and C. Melek, 2017. Investigation of the effect of sports participation on the physical ed ucation lessons of sport education. CBU Journal of Physical Education Sports Science, 12(2): 1-11.

Kayışoğlu, N.B., M. Altınkök, C. Temel and Y. Yüksel, 2015. Examination of the sporting behaviors of the secondary school students' physical education course: Karabük Province case. International Journal of Social Sciences and Education Research, 1(3): 10451056 .

Koç, Y., 2017. A study on the relationship between high school students' physical education course sportsmanship behaviors and their patience levels. Recent Developments in Education: 191-200.

Lumpkin, A., K. Stoll and M. Beller, 2003. Sport ethics: Application for fair play. 3rd Edn., USA: McGrawHill.

MEB, 2018. Physical education and sport course curriculum (Secondary School 5, 6, 7 and 8 Classes) Ankara 1-30.

Orhun, A., 1992. Fair play is an educational principle in school sport. Sports Sciences II. National Congress Proceedings, 20,22 November 1992, Hacettepe University, Ankara.

Pay, A., 2012. Gestalt approach and learning, educational psychology. Maya Academy.

Pehlivan, Z., 2004. The role of school sports in the development of the concept of fair play. SPORMETRE Journal of Physical Education and Sports Sciences, 2: 49-53. 
Renson, R., 2009. Fair play: Its origins and meanings in sport and society. Kinesiology: International Journal of Fundamental and Applied Kinesiology, 41(1): 5-18.

Sahin, A., 2016. The concept of fair play in sport: The importance of fair play (Fair play Concept in Sport). International Journal of International Multidisciplinary Academic Researches, 3(1): 25-30.

Sezen-Balçıkanlı, G., 2010. Turkish adaptation of multidimensional sportism orientation scale: Validity and reliability study. Gazi Journal of Physical Education and Sports Sciences, 15(1): 1-10.

Sezen-Balçikanl, G., 2017. The moral goal of competition sports. Journal of Sports and Performance Research, 8(1): 47-52.

Stornes, T. and E. Bru, 2002. Sportspersonship and perceptions of leadership: An investigation of adolescent handball players' perceptions of sportspersonship and associations with perceived leadership. European Journal of Sport Science, 2(6): 1-15. Available at: https://doi.org/10.1080/17461391.2002.10142577.

Tel, M., Ç. Yaman and M. Altan, 2017. Sports sciences faculty students' views on sports behavior. International Journal of Cultural and Social Research (UKSAD), 3(2): 16-26.

Tsai, E. and L. Fung, 2005. Sportspersonship in youth basketball and volleyball players. Athletic Insight, 7(2): 37-46.

Vallerand, R.J., M.S. Fortier and F. Guay, 1997. Self-determination and persistence in a real-life setting: Toward a motivational model of high school dropout. Journal of Personality and Social Psychology, 72(5): 1161-1176. Available at: https://doi.org/10.1037//00223514.72.5.1161.

Veronica, P., 2010. The importance of moral training in sports performance. Procedia-Social and Behavioral Sciences, 2(2): 869-874. Available at: https://doi.org/10.1016/j.sbspro.2010.03.118.

Yakup, K., 2013. Physical education course of sporting behavior scale (BEDSSS): Validity and reliability study. Erzincan Univ ersity Faculty of Education Journal, 15(1): 96-114

Yıldıran, I., 2004. Fair play: Scope of view and development prospects in Turkey. Gazi Journal of Physical Education and Sports Sciences, 9(4): 3-16.

Yilmaz, A., O.K. Esenturk and E.L. Ilhan, 2017. Sportsmanship in terms of moral development of middle school students in terms of moral development of students. Journal of Human Sciences, 14(4): 4969-4988. Available at: https://doi.org/10.14687/jhs.v 14i4.4869. 